\title{
EFEKTIVITAS MODEL PEMBELAJARAN BERBASIS MASALAH DAN INKUIRI TERHADAP KARAKTER KOMUNIKATIF PADA MATERI TERMOKIMIA
}

\author{
Vivin Wulandari ${ }^{1 *}$, Maria Erna ${ }^{1}$ dan Rasmiwetti ${ }^{1}$ \\ ${ }^{7}$ Pendidikan Kimia, Fakultas Keguruan dan Ilmu Pendidikan, Program Pascasarjana \\ Universitas Riau, Jalan Bina Widya 25, Pekanbaru, 28293, Indonesia \\ *E-mail: vivinwulandari38@gmail.com
}

\begin{abstract}
ABSTRAK
Penelitian tentang penerapan model pembelajaran berbasis masalah $(P B L)$ dan inkuiri telah dilakukan untuk melihat model pembelajaran yang lebih efektif terhadap karakter komunikatif peserta didik pada pokok bahasan termokimia di kelas XI SMA Negeri 1 Bandar Seikijang, Pelalawan. Bentuk penelitian yang dilakukan adalah penelitian kuasi-eksperimen dengan desain non equivalen control posttest design. Waktu pengambilan data mulai dari bulan september-oktober 2018 sebanyak 4 kali pertemuan. Sampel merupakan dua kelas yang dipilih dari empat kelas yang ada, yaitu kelas XI MIPA 1 berjumlah 25 peserta didik dan XI MIPA 2 berjumlah 21 peserta didik. Teknik pengumpulan data dalam penelitian ini yaitu tes dan kuisioner (angket), tes dilakukan dengan soal sebanyak 30 butir dan angket sebanyak 18 butir pernyataan. Teknik analisis data yang digunakan yaitu dengan menghitung skor rata-rata untuk soal tes dan menghitung persentase karakter komunikatif untuk soal non tes. Berdasarkan hasil penelitian, pengolahan data akhir diperoleh persentase hasil belajar pada kelas $P B L$ sebesar $78,85 \%$ dan pada kelas inkuiri sebesar $81,98 \%$. Selain itu, persentase karakter komunikatif peserta didik yang diajar dengan model $P B L$ sebesar $78,15 \%$ dan kelas inkuiri sebesar $83,75 \%$, artinya penerapan model pembelajaran inkuiri lebih efektif digunakan dalam membangun karakter komunikatif peserta didik pada materi termokimia di kelas XI SMA Negeri 1 Bandar Seikijang, Pelalawan.
\end{abstract}

Kata kunci: model pembelajaran berbasis masalah, inkuiri, karakter komunikatif, termokimia

\section{ABSTRACT}

Research on the application of the problem based learning (PBL) and Inquiry Based Learning (IBL) models has been conducted to compare a more effective learning model of students' communicative character on the subject of Thermochemistry in class XI of SMAN 1 Bandar Seikijang, Pelalawan. The form of research conducted was quasi-experimental research with the design of The randomized posttest only. The time of data collection starts from september-october 2018. The sample was two classes chosen from four existing classes, namely class XI MIPA 1 and XI MIPA 2. Data collection was done with 30 questions test and 13 items questionnaire. The data analysis technique used is by calculating the average score for the test questions and calculating the percentage of communicative characters for the non-test questions. Based on observations, the final data processing obtained the percentage of learning outcomes at PBL class of $78.85 \%$ and in the IBL class at $81,98 \%$. While the percentage of communicative characters of students taught with PBL models amounted to $78,15 \%$ and in the inquiry class at $83,75 \%$, it means that the application of inquiry learning models was more effective to be used in building communicative characters on the subject of Thermochemistry in class XI of SMAN 1 Bandar Seikijang, Pelalawan.

Keywords: problem based learning model, inquiry, communicative character, thermochemistry 
Efektivitas Model Pembelajaran Berbasis Masalah dan Inkuiri terhadap Karakter Komunikatif pada Materi Termokimia

\section{PENDAHULUAN}

Karakter diartikan sebagai watak, sifat, akhlak ataupun kepribadian yang membedakan seorang individu dengan individu lainnya. Karakter dapat dikatakan juga sebagai keadaan yang sebenarnya dari dalam diri seorang individu, yang membedakan antara individu yang satu dengan individu lain. Pendidikan karakter merupakan suatu sistem yang menanamkan nilai-nilai karakter kepada seorang individu, yang meliputi: ilmu pengetahuan, kesadaran, kemauan dan tindakan untuk dapat melaksanakan nilai-nilai tersebut baik terhadap Tuhan YME, dirinya sendiri, orang lain, lingkungannya maupun bangsa dan negaranya.

Terdapat 18 karakter atau nilai pendidikan menurut Kementrian Pendidikan Nasional. Karakter tersebut antara lain religius, jujur, toleransi, disiplin, kerja keras, kreatif, mandiri, demokratis, rasa ingin tahu, semangat kebangsaan dan nasionalisme, cinta tanah air, menghargai prestasi, komunikatif, cinta damai, gemar membaca, peduli lingkungan, peduli sosial, dan tanggung jawab. Salah satu karakter yang sangat penting dimiliki seorang peserta didik yaitu karakter komunikatif (Nasution dkk., 2013).

Menurut Elfindri (2012) orang yang komunikatif adalah orang yang mudah bergaul dengan orang lain dan biasanya selain mampu menyampaikan, juga mampu mendengarkan apa yang disampaikan oleh orang lain untuk kemudian direspon dengan cara yang tepat. Orang yang komunikatif biasanya dapat dengan mudah diterima di lingkungannya.

Sikap komunikatif diambil sebagai salah satu permasalahan dalam penelitian ini karena sikap tersebut dapat mempengaruhi kemampuan peserta didik dalam berdiskusi kelompok melalui penerapan metode pembelajaran tutor sebaya yang menuntut peserta didik untuk mampu berdiskusi dengan peserta didik lainnya sehingga dalam diskusi tersebut akan tercipta suasana diskusi yang aktif.

Berdasarkan observasi yang telah dilakukan di SMAN 1 Bandar Seikijang kemampuan komunikasi peserta didik pada saat proses pembelajaran masih belum terlaksana dengan baik. Peserta didik yang kurang berkomunikasi dalam belajar disebabkan karena kurang dapat memahami materi pelajaran yang diterima, sehingga mereka sulit untuk berargumen pada proses pembelajaran. Selain itu, peserta didik hanya bergantung kepada guru sehingga pembelajaran berpusat pada guru.

Proses pembelajaran harus diubah dari teacher centered ke student centered, metode yang semula didominasi oleh guru sebagai sumber informasi belajar peserta didik berganti ke aktivitas peserta didik yang lebih mandiri, dan pendekatan yang semula lebih banyak bersifat "tekstual" berubah menjadi "kontekstual" dengan keseimbangan antara pengetahuan, keterampilan, dan sikap. Sesuai dengan kurikulum 2013 revisi peserta didik dituntut untuk mampu berinteraksi, berargumen, berdebat, dan berkolaborasi sehingga fungsi guru dari pengajar berubah dengan sendirinya menjadi fasilitator bagi peserta didik dalam proses belajar mengajar di kelas.

Kurikulum 2013 revisi ini diharapkan dapat menjadi solusi untuk menghadapi tantangan pendidikan di abad ke 21. Chaeruman (2008) mengatakan bahwa tantangan pendidikan abad ke 21 menurut Perserikatan BangsaBangsa (PBB) adalah membangun masyarakat berpengetahuan (knowledgebased society) yang memiliki 
Efektivitas Model Pembelajaran Berbasis Masalah dan Inkuiri terhadap Karakter Komunikatif pada Materi Termokimia

keterampilan, mahir Teknologi Informasi dan Komunikasi (TIK) dan media (ICT and media literacy skills), (2) keterampilan berpikir kritis (critical thinking skill), (3) keterampilan memecahkan masalah (problem solving skills), (4) keterampilan berkomunikasi efektif (effective communication skills); dan (5) keterampilan bekerjasarna secara kolaboratif (collaborative skills). Berdasarkan hal tersebut, diperlukan suatu model pembelajaran yang mampu membentuk keterampilan berkomunikasi peserta didik yang efektif pada saat proses pembelajaran.

Terdapat empat model pembelajaran yang direkomendasikan dan mendukung pembelajaran pada kurikulum 2013. Keempat model pembelajaran itu yaitu Inquiry, Discovery, Problem Based Learning (PBL), dan Project Based Learning (PJBL). Peneliti memilih menerapkan model inkuiri dan PBL dengan beberapa pertimbangan seperti yang dijelaskan Lutvia (2016) bahwa model pembelajaran inkuiri dan PBL memiliki banyak kesamaan seperti tertera pada Tabel 1.

Tabel 1. Persamaan Model Inkuiri dan PBL

\begin{tabular}{|c|l|l|l|}
\hline \multirow{2}{*}{ No } & \multirow{2}{*}{ Indikator } & \multicolumn{2}{|c|}{ Model } \\
\cline { 3 - 4 } 1. & $\begin{array}{l}\text { Dominasi } \\
\text { Sumber Belajar } \\
\text { Peserta didik }\end{array}$ & Mandiri & Mandiri \\
\hline 2. & Jenis Tugas & $\begin{array}{l}\text { Kelompok } \\
\text { atau } \\
\text { individu }\end{array}$ & $\begin{array}{l}\text { Kelompo } \\
\text { k atau } \\
\text { individu }\end{array}$ \\
\hline 3. & $\begin{array}{l}\text { yang Diangkat } \\
\text { dalam } \\
\text { Pembelajaran }\end{array}$ & $\begin{array}{l}\text { Mang } \\
\text { sudah ada }\end{array}$ & $\begin{array}{l}\text { Masalah } \\
\text { yang } \\
\text { sudah } \\
\text { ada }\end{array}$ \\
\hline 4. & $\begin{array}{l}\text { Tujuan Utama } \\
\text { Pembelajaran }\end{array}$ & $\begin{array}{l}\text { Berpikir } \\
\text { kritis }\end{array}$ & $\begin{array}{l}\text { Berpikir } \\
\text { kritis }\end{array}$ \\
\hline 5. & $\begin{array}{l}\text { Proses } \\
\text { Penilaian }\end{array}$ & $\begin{array}{l}\text { Satu } \\
\text { Waktu }\end{array}$ & $\begin{array}{l}\text { Satu } \\
\text { Waktu }\end{array}$ \\
\hline 6. & $\begin{array}{l}\text { Jenis Evaluasi } \\
\text { Penilaian }\end{array}$ & $\begin{array}{l}\text { Kualitatif } \\
\text { atau }\end{array}$ & $\begin{array}{l}\text { Kualitatif } \\
\text { atau }\end{array}$ \\
\hline
\end{tabular}

\begin{tabular}{|c|l|l|l|}
\hline 7. & $\begin{array}{l}\text { Kuantitatif } \\
\text { Peralatan yang } \\
\text { Dibutuhkan }\end{array}$ & $\begin{array}{l}\text { Kuantitati } \\
\mathrm{f}\end{array}$ \\
\hline 8. & $\begin{array}{l}\text { Teknis dan } \\
\text { Sistematika } \\
\text { Pembelajaran }\end{array}$ & $\begin{array}{l}\text { Diarahkan } \\
\text { guru }\end{array}$ & $\begin{array}{l}\text { Sedikit } \\
\text { n gurahk }\end{array}$ \\
\hline 9. & Peran Guru & Moderator & $\begin{array}{l}\text { Moderat } \\
\text { or }\end{array}$ \\
\hline 10. & $\begin{array}{l}\text { Pendekatan } \\
\text { yang Dipakai } \\
\text { untuk } \\
\text { Memecahkan } \\
\text { Masalah }\end{array}$ & $\begin{array}{l}\text { Multi } \\
\text { disipliner }\end{array}$ & $\begin{array}{l}\text { Multi } \\
\text { disipliner }\end{array}$ \\
\hline
\end{tabular}

Model PBL merupakan model yang direkomendasikan kurikulum di dalam suatu pembelajaran. Model ini dapat digunakan untuk mengembangkan kemampuan intelektual dan memecahkan suatu masalah sehingga peserta didik dapat menemukan konsep materi melalui pengetahuan yang dimilikinya. Terdapat komunitas belajar dalam pelaksanaan model ini, peserta didik tidak hanya belajar secara kooperatif melainkan secara kolaboratif. Pembelajaran secara kolaboratif menuntut peserta didik untuk dapat berkomunikasi lebih efektif baik dengan sesama peserta didik yang ada di dalam komunitasnya maupun dengan guru dan peserta didik yang ada di kelas. Hal ini sesuai dengan yang diungkapkan oleh Duran (2014) bahwa model PBL dapat meningkatkan komunikasi peserta didik berdasarkan kerja sama dan tidak berdasarkan persaingan. Sehingga peserta didik juga dituntut untuk dapat belajar mandiri bersama komunitas belajarnya dan bukan bergantung pada guru.

Selain model pembelajaran $P B L$ yang telah dijelaskan di atas, terdapat satu model pembelajaran yang menempatkan peserta didik lebih banyak belajar sendiri untuk menemukan konsep-konsep dan prinsip ilmiah serta mengembangkan kreativitas 
Efektivitas Model Pembelajaran Berbasis Masalah dan Inkuiri terhadap Karakter Komunikatif pada Materi Termokimia

dalam pemecahan masalah. Model pembelajaran ini disebut model pembelajaran inkuiri. Model inkuiri merupakan rangkaian pembelajaran yang menekankan kepada proses berfikir dan analisis untuk mencari dan menemukan sendiri jawaban dari suatu masalah yang dipertanyakan sehingga dapat mengembangkan proses mental meliputi rasa ingin tahu, berpikir kritis, penyelidikan dan pemecahan masalah.

Dalam konteks pembelajaran inkuiri pembelajaran berfokus pada peserta didik: apa itu pengetahuan baru bagi mereka atau tidak, masalah yang ada terjadi dalam banyak kasus dan pengetahuan baru dalam kehidupan sehari-hari. Selain itu, perlu dicatat bahwa investigasi tidak selalu melibatkan pengujian empiris (Pedaste et al., 2015).

Walaupun kedua model di atas sama-sama berorientasi pada penyelesaian masalah, namun terdapat beberapa perbedaan yang tampak dari model pembelajaran berbasis masalah $(P B L)$ dan inkuiri, yaitu konsep belajarnya. $P B L$ lebih memfokuskan peserta didik pada belajar dengan "penyelesaian dari masalah" sedangkan inkuiri memfokuskan peserta didik pada belajar "penyelidikan terhadap masalah". Pada proses belajar PBL peserta didik berorientasi memproses informasi yang dikumpulkannya dari berbagai sumber untuk menjawab segala bentuk permasalahan yang diberikan oleh guru. Sedangkan pada proses belajar inkuiri peserta didik distimulus untuk aktif mengajukan pertanyaan-pertanyaan yang baik, dan jawaban tidak harus didapatkan dari guru tetapi peserta didik lain juga memiliki kesempatan untuk menjawab pertanyaan yang diajukan. Hal ini senada dengan yang dinyatakan Handoyono dan Arifin (2016) bahwa pada model inkuiri permasalahanpemasalahan harus diindentifikasi sendiri oleh peserta didik, sedangkan pada metode $P B L$ permasalahan-permasalahan sudah teridentifikasi oleh guru. Dalam model inkuiri peserta didik merumuskan permasalahan dan kemudian melakukan kegiatan penyelidikan untuk memecahkan permasalahan. Sedangkan dalam pembelajaran yang menggunakan $P B L$, peserta didik disuguhkan permasalahan yang nyata di dalam kehidupan sehari-hari dan kemudian melakukan pencarian informasi untuk memecahkan permasalahan.

Secara operasional, peserta didik mempelajari berbagai metode dalam mencari informasi, mengembangkan cara untuk mendapatkan pengetahuan baru, dan mengatur diri mereka secara bersama untuk menciptakan solusi yang layak untuk pemecahan suatu masalah (Duch et al., 2001). Sebuah efek dari proses pembelajaran adalah dapat menciptakan peserta didik yang mampu mengembangkan keterampilan komunikasi yang kuat dan efektif. Berdasarkan observasi yang telah dilakukan di SMAN 1 Bandar Seikijang kemampuan komunikasi peserta didik pada saat proses pembelajaran masih belum terlaksana dengan baik. Peserta didik yang kurang berkomunikasi dalam belajar disebabkan karena kurang dapat memahami materi pelajaran yang diterima, sehingga mereka sulit untuk berargumen pada proses pembelajaran dan hasil belajar peserta didik belum efektif.

Pembelajaran yang efektif telah mendapatkan pemahaman tentang proses individu dan sosial diperlukan untuk menjadi pelajar yang efektif. Ini bukan hanya akuisisi strategi tertentu, tetapi pemantauan dan peninjauan pembelajaran untuk melihat apakah strategi itu efektif. Di saat tekanan untuk menghasilkan hasil cepat, dapat dimengerti bahwa beberapa orang akan berusaha untuk 
Efektivitas Model Pembelajaran Berbasis Masalah dan Inkuiri terhadap Karakter Komunikatif pada Materi Termokimia

"mempercepat belajar". Sikap ini lebih sering tentang mengajar daripada belajar. Ini mungkin bukan pembelajaran yang efektif.

Sudah banyak penelitian yang dilakukan oleh para peneliti untuk memperbaiki hasil belajar peserta didik. Peneliti menerapkan model PBL pada materi termokimia. Termokimia tergolong materi kimia yang dirasa sulit oleh peserta didik, sehingga harus ada suatu gagasan yang dapat merubah sudut pandang peserta didik. Salah satu upaya yang dapat dilakukan yaitu dengan memberikan suatu model pembelajaran yang tepat seperti model yang direkomendasikan di dalam kurikulum, misalnya $P B L$ dan inkuiri.

Penelitian-penelitian terkait model PBL sudah banyak dilakukan, diantaranya hasil penelitian Lathiifah dkk. (2015) peningkatan hasil belajar dan kerja sama peserta didik yang diajarkan dengan menerapkan model $P B L$ lebih tinggi daripada peningkatan hasil belajar dan kerjasama peserta didik yang diajarkan dengan menerapkan model biasa. Peningkatan hasil belajar peserta didik sebesar $76 \%$ dengan rata-rata nilai 85,86 . Nasution dkk. (2013) menunjukkan bahwa model PBL disertai media internet adalah model yang memiliki konstribusi untuk meningkatkan hasil belajar kimia, karakter komunikatif dan percaya diri peserta didik pada pembelajaran kimia larutan. Kumar dan Refaei (2017) dalam penelitiannya yang berjudul "Pedagogi Pembelajaran Berbasis Masalah Memupuk Peserta didik Berpikir Kritis Tentang Menulis" menjabarkan temuan awal yang menunjukkan bahwa pemikiran kritis peserta didik tentang menulis meningkat dengan penggunaan pedagogi PBL. Sedangkan hasil penelitian Hidian (2015) penggunaan model pembelajaran inkuiri lebih efektif dibandingkan pembelajaran biasa dengan skor gain kelas inkuiri lebih besar daripada kelas kontrol yaitu N-Gain
$0,70>0,45$. Mundilarto (2013) menyatakan pembelajaran inkuiri efektif untuk meningkatkan karakter peserta didik SMA pada pembelajaran fisika.

Berdasarkan pemaparan tersebut, maka peneliti tertarik untuk melakukan suatu penelitian tentang perbedaan keefektivan dari dua model pembelajaran, yaitu model pembelajaran berbasis masalah $(P B L)$ dan inkuiri terhadap karakter komunikatif peserta didik. Melalui penelitian ini diharapkan mampu memberikan solusi untuk menghadapi tantangan pendidikan abad ke 21 serta meningkatkan kualitas pendidikan di sekolah, terutama memperkokoh peranan kimia bagi kehidupan.

\section{METODE PENELITIAN}

Penelitian ini dilakukan pada dua kelas eksperimen dengan bentuk penelitian kuasieksperimen dengan desain non equivalen control posttest design.

Penelitian ini dilaksanakan di SMAN 1 Bandar Seikijang kelas XI semester ganjil tahun ajaran 2018/2019 pada akhir september-oktober 2018 sebanyak 4 kali pertemuan. Populasi dalam penelitian ini adalah peserta didik kelas XI SMAN 1 Bandar Seikijang yang terdiri dari empat kelas. Dari populasi tersebut diambil dua kelas yang bersifat representatif (mewakili), yaitu XI MIPA 1 dan XI MIPA 2 yang masing-masing terdiri dari 25 peserta didik dan 21 peserta didik.

Adapun variabel yang terdapat dalam penelitian ini terdiri dari variabel bebas yaitu model pembelajaran PBL dan inkuiri, sedangkan variabel terikat adalah hasil belajar kimia peserta didik berupa kognitif dan karakter komunikatif. Materi ajar kimia yang dipilih adalah termokimia, karena materi ini tergolong materi yang sulit. 
Efektivitas Model Pembelajaran Berbasis

Masalah dan Inkuiri terhadap Karakter

Komunikatif pada Materi Termokimia

Instrumen yang digunakan adalah instrumen tes berupa tes pilihan berganda sebanyak 30 butir soal untuk memperoleh data hasil belajar kognitif dan instrumen angket kuisioner sebanyak 18 butir pernyataan untuk memperoleh data karakter komunikatif. Instrumen angket telah divalidasi terlebih dahulu oleh tiga orang validator kemudian diujicobakan kepada 20 peserta didik untuk melihat validitas pernyataan yang ada pada kuisioner. Dari 20 butir pernyataan, setelah dilakukan uji validitas dan realibilitas maka diperoleh 18 butir pernyataan yang valid. Penilaian kuisioner menggunakan skala Likert dengan skor 1-4 dengan skor maksimal 72 poin. Proses pembelajaran dikatakan berhasil/efektif apabila terjadi perubahan yang positif dari peserta didik seluruhnya atau setidak-tidaknya sebagian besar (75\%).

Prosedur penelitian ini dapat dilihat pada Gambar 1.

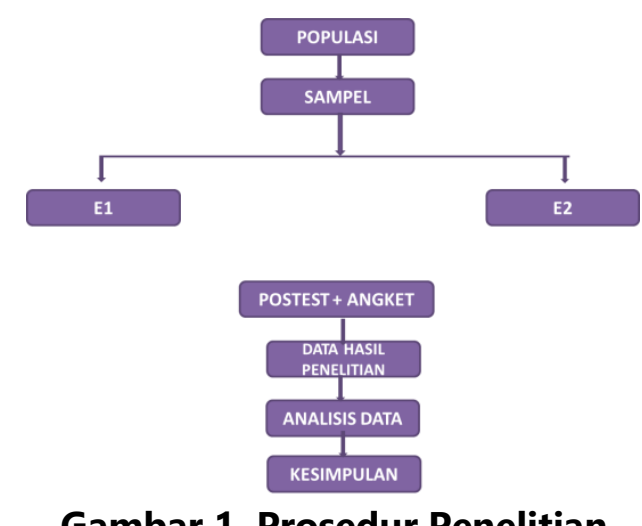

Penelitian dilakukan pada dua kelas eksperimen, kelas eksperimen 1 (E1) adalah kelas yang menerapkan model pembelajaran berbasis masalah dan kelas eksperimen 2 (E2) adalah kelas yang menerapkan model pembelajaran inkuiri. Langkah pembelajaran dari masing-masing model adalah sebagai berikut:
Langkah-langkah pembelajaran model PBL menurut Lynch dan Wolcott (2001):

1. Identifikasi masalah, informasi yang relevan, dan ketidakpastian

2. Jelajahi interpretasi dan koneksi

3. Memprioritaskan alternatif dan mengkomunikasikan kesimpulan

4. Integrasikan, pantau, dan perbaiki strategi untuk mengatur kembali masalah.

Langkah-langkah pembelajaran pada model pembelajaran inkuiri menurut Pedaste et al. (2015):

1. Orientasi, proses merangsang rasa ingin tahu tentang suatu topik dan mengatasi tantangan belajar melalui sebuah pernyataan masalah

2. Konseptualisasi, proses menyatakan pertanyaan berbasis teori dan / atau hipotesis.

3. Investigasi, proses perencanaan eksplorasi atau bereksperimen, mengumpulkan dan menganalisis data berdasarkan desain eksperimental atau eksplorasi.

4. Kesimpulan, proses menggambar kesimpulan dari data.

5. Diskusi, proses menyajikan temuantemuan tertentu fase atau seluruh siklus pertanyaan oleh berkomunikasi dengan orang lain dan / atau mengendalikan seluruh proses pembelajaran atau tahapannya dengan melibatkan dalam kegiatan reflektif. Komunikasi proses menyajikan hasil penyelidikan fase atau seluruh siklus pertanyaan kepada orang lain (teman sebaya, guru) dan mengumpulkan umpan balik dari mereka.

Data yang diperoleh kemudian dianalisis dengan menghitung rata-rata dan persentase nilai post-test untuk memperoleh nilai kognitif. Sedangkan untuk melihat karakter komunikatif analisis dilakukan dengan menghitung persentase skor angket dari masing-masing kelas. Data instrumen tes 
Efektivitas Model Pembelajaran Berbasis Masalah dan Inkuiri terhadap Karakter Komunikatif pada Materi Termokimia

yang diperoleh diuji normalitas dan homogenitasnya menggunakan SPSS versi 20 dengan taraf signifikansi sebesar $5 \%$. Setelah data yang diperoleh diyakini telah memenuhi uji hipotesis dan layak dijadikan sebagai sampel penelitian. Pengujian hipotesis yang dipilih adalah independent sample t-test untuk mengetahui adakah perbedaan yang signifikan antara karakter komunikatif peserta didik yang diajar dengan model $P B L$ dan inkuiri.

\section{HASIL DAN PEMBAHASAN}

Dari hasil penelitian yang dilakukan didapatkan data hasil post-test dan persentase nilai angket komunikatif pada kelas yang menggunakan model $P B L$ dan inkuiri. Data post-test kedua kelas diperoleh dari instrumen tes pilihan berganda yang berjumlah 30 butir soal yang diberikan kepada peserta didik setelah masing-masing diberikan pembelajaran dengan model $P B L$ dan inkuiri. Data hasil post-test dari kelas yang diberi perlakuan dengan menggunakan model $P B L$ maupun Inkuiri dapat dilihat pada Tabel 2.

Tabel 2. Nilai Post-test

\begin{tabular}{|l|c|c|}
\hline \multirow{2}{*}{$\begin{array}{c}\text { Model } \\
\text { Pembelajaran }\end{array}$} & \multicolumn{2}{|c|}{ Post-test } \\
\cline { 2 - 3 } & $\begin{array}{c}\text { Rata- } \\
\text { Rata }\end{array}$ & Persentase \\
\hline PBL & 78,85 & $78,85 \%$ \\
\hline Inkuiri & 81,98 & $81,98 \%$ \\
\hline
\end{tabular}

Hasil rata-rata nilai post-test pada Tabel 2 menunjukkan bahwa nilai rata-rata kelas yang diajar dengan menggunakan model pembelajaran inkuiri lebih tinggi dibandingkan kelas yang diajar dengan model pembelajaran berbasis masalah (PBL) yaitu 81,98 dan 78,85 pada materi termokimia. Hal ini terjadi karena pada model pembelajaran inkuiri terdapat tahapan belajar yang membimbing peserta didik dalam menyelesaikan masalah yang diberikan pada awal kegiatan. Peserta didik diminta untuk memberikan hipotesis mengenai masalah yang diberikan, kemudian untuk membuktikan hipotesis, peserta didik melakukan penyelidikan melalui percobaan. Hasil pengamatan yang diperoleh kemudian disesuaikan dengan hipotesis yang telah peserta didik tuliskan. Dengan bantuan berbagai sumber belajar peserta didik membuat suatu kesimpulan dari materi belajar yang sedang dipelajari. Model inkuiri membuat peserta didik memiliki proses pola pikir induktif, di mana di awal kegiatan peserta didik dihadapkan dengan suatu masalah, kemudian peserta didik mengumpulkan data melalui penemuannya sendiri dalam sebuah percobaan sederhana yang pada akhirnya digunakan untuk menjawab permasalahan yang diberikan oleh guru pada proses pembelajaran. Hal ini senada dengan Egen dan Kauchak (Trianto, 2007) yang dijabarkan dalam langkah pembelajaran inkuiri, di mana peserta didik pada awal kegiatan dihadapkan sebuah masalah dan kemudian dengan merancang percobaan peserta didik memperoleh data yang digunakan untuk menjawab masalah yang diberikan oleh guru.

Nilai rata-rata post-test kelas yang diajar dengan model $P B L$ lebih rendah dikarenakan terdapat perbedaan yang mendasar pada kedua model pembelajaran ini. Sebelumnya telah dijelaskan bahwa model pembelajaran inkuiri membimbing peserta didik belajar dengan proses berpikir induktif, sedangkan pada model $P B L$ membimbing peserta didik belajar dengan proses berpikir deduktif. Untuk memecahkan masalah yang diberikan pada awal kegiatan, peserta didik harus mencari informasi dari berbagai sumber. Sumber belajar yang digunakan dalam penelitian adalah buku teks pelajaran, LKPD (lembar kerja peserta didik) dan internet. 
Efektivitas Model Pembelajaran Berbasis Masalah dan Inkuiri terhadap Karakter Komunikatif pada Materi Termokimia

Pada saat belajar menggunakan model $P B L$, peserta didik lebih aktif membaca dan mencari informasi untuk menjawab semua pertanyaan yang diberikan guru. Sehingga kekuatan pemahaman peserta didik terhadap materi tidak terlalu maksimal. Berbeda dengan model inkuiri yang memfokuskan peserta didik pada analisis melalui percobaan. Hal ini akan mengasah kemampuan peserta didik dalam menyelasaikan masalah yang diberikan melalui penemuan-penemuan yang diperoleh dari percobaan yang dilakukan.

Adanya peningkatan hasil belajar siswa dengan menggunakan model inkuiri dikarenakan pada proses pembelajaran dengan model pembelajaran inkuiri, peserta didik belajar sendiri menemukan konsepkonsep materi pembelajaran. Model ini termasuk model pemrosesan informasi yang menekankan pada peserta didik bagaimana cara berpikir dan penemuannya terhadap cara-cara mengolah informasi. Model pembelajaran inkuiri cocok digunakan untuk peserta didik SMA karena guru memberikan banyak peran dalam memberikan arahan untuk membimbing peserta didik dalam menyelesaikan masalah (Jerminuari, 2016).

Tahapan-tahapan inkuiri membuat peserta didik tidak hanya menerima penjelasan dari guru saja, tetapi ada interaksi antar peserta didik di mana peserta didik berusaha untuk menemukan sendiri cara menyelesaikan permasalahan yang ada. Sesuai dengan penelitian Yolanda (2015) bahwa hasil belajar kognitif peserta didik akan semakin tinggi dengan adanya tahap-tahap penyelidikan (pengumpulan data) dan pemecahan masalah (analisis data) dalam model inkuiri (Putri \& Meinita, 2013). Hal ini juga selaras dengan penelitian yang dilakukan Tyas dan Lazulva (2018) bahwa pembelajaran inkuiri mampu membuat peserta didik memiliki hasil kognitif

64 yang baik dan memberikan pengaruh sekitar 9,94\% terhadap hasil belajar.

Dari hasil penelitian dapat diketahui bahwa model pembelajaran inkuiri lebih efektif digunakan jika ditinjau dari hasil belajar peserta didik. Namun selain itu jika dilihat dari kemampuannya dalam meningkatkan karakter komunikatif pada peserta didik diperoleh data yang disajikan pada tabel 3 .

Tabel 3. Nilai Rata-Rata Angket Karakter Komunikatif

\begin{tabular}{|l|c|}
\hline \multicolumn{1}{|c|}{$\begin{array}{c}\text { Model } \\
\text { Pembelajaran }\end{array}$} & $\begin{array}{c}\text { Karakter } \\
\text { Komunikatif }\end{array}$ \\
\hline PBL & 78,15 \\
\hline INKUIRI & 83,75 \\
\hline
\end{tabular}

Model PBL dan inkuiri merupakan dua model yang direkomendasikan kurikulum di dalam suatu pembelajaran. Kedua model ini memiliki persamaan dalam mengembangkan kemampuan intelektual peserta didik dengan pengetahuan yang dimilikinya dalam upaya peserta didik memecahkan suatu masalah sehingga peserta didik dapat menemukan suatu konsep dari materi yang dipelajarinya. Terdapat komunitas belajar dalam pelaksanaan kedua model ini, peserta didik tidak hanya belajar secara kooperatif melainkan secara kolaboratif.

Pembelajaran secara kolaboratif menuntut peserta didik untuk dapat berkomunikasi lebih efektif baik dengan sesama peserta didik yang ada di dalam komunitasnya maupun dengan guru dan peserta didik yang ada di kelas. Seperti yang diungkapkan oleh Duran (2014) bahwa model pembelajaran PBL dan inkuiri dapat meningkatkan komunikasi peserta didik berdasarkan kerja sama dan tidak berdasarkan persaingan. Peserta didik juga dituntut untuk dapat belajar mandiri bersama komunitas belajarnya dan bukan bergantung pada guru. 
Efektivitas Model Pembelajaran Berbasis Masalah dan Inkuiri terhadap Karakter Komunikatif pada Materi Termokimia

Data hasil penelitian dianalisis dengan menghitung total skor yang dirata-ratakan dan kemudian dipersentasekan secara klasikal. Pada kelas dengan menggunakan model $P B L$ rata-rata karakter komunikatif sebesar $78,15 \%$. Sedangkan pada kelas yang diajar dengan menggunakan model pembelajaran inkuiri, persentase karakter komunikatif peserta didik secara klasikal sebesar 83,75\%. Deskripsi data karakter komunikatif dan hasil post-test peserta didik pada masing-masing kelas dapat dilihat pada Gambar 2.

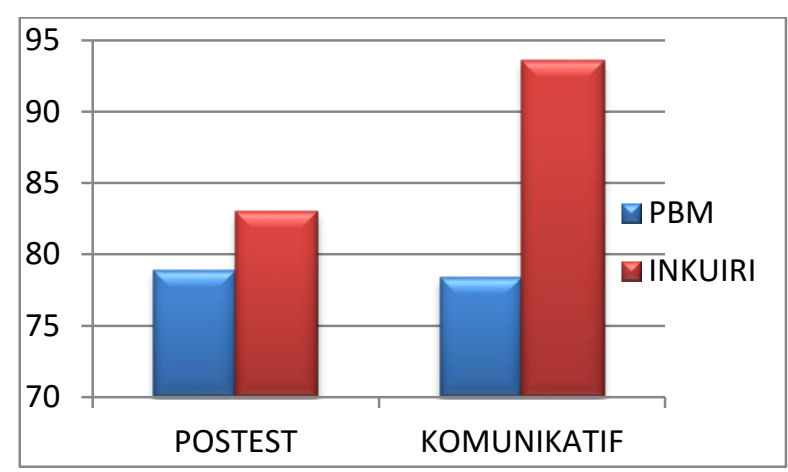

Gambar 2. Deskripsi hasil belajar dan karakter komunikatif peserta didik

Tedapat 4 indikator karakter komunikatif di sekolah dan di kelas menurut Kemendiknas (2010) yaitu:

1. Tindakan yang memperlihatkan rasa senang berbicara.

2. Memiliki kemampuan berkomunikasi yang baik.

3. Mudah bergaul.

4. Bekerja sama dengan orang lain.

Model pembelajaran inkuiri mampu meningkatkan karakter komunikatif peserta didik karena pada penerapannya model ini menuntut para peserta didik untuk bekerja sama dalam kelompok untuk memecahkan permasalahan yang dihadapi. Karakter komunikatif merupakan karakter yang perlu ditanamkan pada peserta didik, peserta didik dituntut untuk mampu berkomunikasi dengan baik, antar sesama peserta didik maupun dengan guru.

Berbeda dengan model $P B L$, pada model pembelajaran inkuiri terdapat tahap di mana peserta didik harus membuat suatu hipotesis dari masalah yang akan diselesaikan. Pada tahap ini peserta didik menjadi sangat aktif dan lebih bebas dalam mengeluarkan pendapatnya. Peserta didik lebih leluasa dalam memberikan jawaban terhadap masalah yang diperoleh melalui analisis data hasil percobaan. Kemudian pada saat diskusi kelompok dilakukan, terjadi perbedaanperbedaan pendapat antar kelompok mengenai pandangan terhadap masalah yang disajikan oleh guru. Diskusi berjalan dengan baik karna peserta didik lebih aktif dalam bertanya, menjawab, maupun memaparkan pendapatnya. Menurut pengamatan peneliti karakter komunikatif lebih terlihat meningkat daripada pembelajaran dengan $P B L$. Karakter komunikatif pada kelas $P B L$ tidak sebaik inkuiri karena pada model $P B L$, peserta didik mencari informasi dari sumber yang sama untuk menyelesaikan masalah. Sehingga tidak terlalu banyak perbedaan dan perdebatan pendapat. Komunikasi yang terbentuk terlihat hanya pada saat persentasi dilakukan, selebihnya sama seperti diskusi pada modelmodel pembelajaran pada umumnya. Hal ini sependapat dengan Thobroni dan Mustofa (2013) yang mengatakan bahwa salah satu kelemahan model PBL adalah tidak semua peserta didik terampil bertanya. Hal ini tentu tidak menggambarkan terpenuhinya indikator karakter komunikatif "tindakan yang memperlihatkan rasa senang berbicara".

Salah satu karakteristik model Inkuiri menurut Gulo (2004) adalah pada pembelajaran inkuiri terjadi kolaborasi antar peserta didik yang memberikan motivasi untuk keterlibatan 
Efektivitas Model Pembelajaran Berbasis Masalah dan Inkuiri terhadap Karakter Komunikatif pada Materi Termokimia

secara berkelanjutan dalam tugas-tugas kompleks dan meningkatkan kesempatan untuk berdialog bersama, dan untuk mengembangkan berbagai keterampilan sosial, salah satunya adalah keterampilan berkomunikasi (communicative skill). Hal ini juga disampaikan Erna dkk. (2018) bahwa pembelajaran dengan menggunakan model inkuiri membuat peserta didik terlibat langsung dalam proses pembelajaran dan adanya peran dalam kelompok membuat peserta didik bertanggungjawab terhadap tugasnya masing-masing serta berkolaborasi dalam menyelesaikan permasalahan yang terdapat dalam LKPD sehingga peserta didik aktif baik dalam mengkomunikasikan hasil diskusi maupun saat kegiatan tanya jawab antar kelompok.

Untuk melihat apakah terdapat perbedaan yang signifikan antara karakter komunikatif peserta didik yang diajar dengan menggunakan model $P B L$ dan inkuiri maka dilakukan Uji-t dan hasilnya dapat dilihat pada Tabel 4.

Tabel 4. Hasil Uji-t Karakter Komunikatif

\begin{tabular}{|l|c|c|c|c|}
\hline & $\mathbf{t}$ & $\mathbf{d f}$ & $\begin{array}{l}\text { Sig.(2- } \\
\text { tailed) }\end{array}$ & Kesimpulan \\
\hline $\begin{array}{l}\text { Pair 1 } \\
\text { Komunikatif- } \\
\text { Model }\end{array}$ & 180, & 45 & 0,000 & Signifikan \\
\hline
\end{tabular}

Hasil uji-t Tabel 4 menunjukkan bahwa ada perbedaan yang signifikan pada karakter komunikatif peserta didik yang diajar dengan model pembelajaran berbasis masalah dan model inkuiri dengan signifikansi 0,000< 0,05 . Dari data yang dihasilkan dapat dilihat bahwa efektivitas kedua model pembelajaran tercapai. Suatu proses belajar mengajar efektif dan bermakna akan berlangsung apabila dapat memberikan keberhasilan bagi peserta didik maupun guru itu sendiri (Muhli, 2012).
Dari hasil penelitian yang dilakukan dapat disimpulkan bahwa model pembelajaran inkuiri lebih efektif digunakan untuk meningkatkan karakter komunikatif pada diri peserta didik. Hal ini juga didukung oleh penelitian yang dilakukan oleh Löfgren et al. (2013) bahwa inkuiri mampu meningkatkan kemampuan komunikatif peserta didik.

\section{KESIMPULAN}

Dari hasil penelitian yang telah dilakukan dapat disimpulkan bahwa model pembelajaran inkuiri pada materi termokimia lebih efektif digunakan untuk membentuk karakter komunikatif peserta didik yaitu sebesar 83,75\%. Selain itu, model pembelajaran ini juga mampu menuntaskan hasil belajar peserta didik sebesar $81,98 \%$. Berdasarkan kesimpulan yang diperoleh, peneliti merekomendasikan kepada guru bidang studi kimia untuk dapat menerapkan model pembelajaran Inkuiri sebagai salah satu alternatif pembelajaran yang dapat digunakan untuk membentuk karakter komunikatif peserta didik khususnya pada pokok materi di kelas XI MIPA SMA. 
Efektivitas Model Pembelajaran Berbasis Masalah dan Inkuiri terhadap Karakter Komunikatif pada Materi Termokimia

\section{DAFTAR PUSTAKA}

Chaeruman, U.A. (2008). Tren dan Tantangan Bagi Teknologi Pendidikan di Abad21.

http://www.ilmupendidikan.net/2017/0

8/25/tren-dan-tantangan-bagiteknolog-pendidikan-di-abad-21.php. Diakses tanggal 15 Juni 2018.

Duch, B. J., Groh, S. E., \& Allen, D. E. (2001). The power of problem-based learning: a practical" how to" for teaching undergraduate courses in any discipline. Stylus Publishing, LLC.

Duran, M. (2014). A Study on 7th Grade Students' Inquiry and Communication Competencies. Procedia-Social and Behavioral Sciences, 116, 4511-4516.

Elfindri. (2012). Pendidikan Karakter. Jakarta: Badouse Media.

Erna, M., Rery, R. U., \& Astuti, W. (2018). Peningkatan Kemampuan Berpikir Kritis Peserta Didik pada Materi Termokimia di SMA Pekanbaru Melalui Penerapan Strategi Pembelajaran Process Oriented Guided Inquiry Learning (POGIL). JRPK: Jurnal Riset Pendidikan Kimia, 8(1), 17-27.

Gulo. W. (2004). Strategi Belajar-Mengajar. Jakarta: PT Grasindo.

Handoyono, N. A., \& Arifin, Z. (2016). Pengaruh inquiry learning dan problem-based learning terhadap hasil belajar PKKR ditinjau dari motivasi belajar. Jurnal Pendidikan Vokasi, 6(1), 31-42.
Hidian, R. (2015). Keefektifan Model Inquiry Based Learning Terhadap Penguasaan Kompetensi Pengoperasian Peralatan Pengendali Daya Tegangan Rendah Kelas XI Di SMK Negeri 1 Sedayu. Skripsi, Fakultas Teknik: Universitas Negri Yogyakarta.

Jerminuari, A. (2016). Pengaruh Model Pembelajaran Inkuiri Terbimbing Terhadap Hasil Belajar Siswa Kelas X di SMA Negeri 1 Rambah Tahun Pembelajaran 2015/2016. Jurnal Ilmiah Mahasiswa FKIP Prodi Biologi, 2(1).

Kemendiknas. (2010). Nilai dan Deskripsi Nilai Pendidikan Budaya dan Karakter Bangsa.

https://www.google.com/search?karakt erpendidikanbudaya. Diakses Tanggal : 29 Juli 2018.

Kumar, R., \& Refaei, B. (2017). Problem-based learning pedagogy fosters students' critical thinking about writing. Interdisciplinary Journal of ProblemBased Learning, 11(2), 1.

Lathiifah, I. J., Zulkardi, Z., \& Somakim, S. (2015). Pengembangan Bahan Ajar Materi Aturan Pencacahan Menggunakan Pembelajaran Berbasis Masalah di SMA. Jurnal Didaktik Matematika, 2(2).

Löfgren, R., Schoultz, J., Hultman, G., \& Björklund, L. (2013). Exploratory Talk in Science Education: Inquiry-Based Learning and Communicative Approach in Primary School. Journal of Baltic Science Education, 12(4).

Lutvia. (2016). Analisis Perbedaan dan Persamaan Model Pembelajaran Inquiry, Discovery, Problem Based Jurnal Tadris Kimiya 4, 1 (Juni 2019): 57-68 
Efektivitas Model Pembelajaran Berbasis Masalah dan Inkuiri terhadap Karakter Komunikatif pada Materi Termokimia

Learning, dan Project Based Learning. Artikel. FKIP UPI.

Lynch, C. L., \& Wolcott, S. K. (2001). Helping your students develop critical thinking skills (IDEA Paper\# 37. In Manhattan, KS: The IDEA Center. Available at http://www. idea. ksu. edu/papers/Idea_Paper_37. pdf.

Muhli, A. (2012). Efektivitas pembelajaran. Jakarta : Wordpress.

Mundilarto, M. (2013). Keefektifan Pendekatan Inquiry Based Learning untuk Meningkatan Karakter Peserta Didik SMA pada Pembelajaran Fisika. Jurnal Pendidikan Matematika dan Sains, 1(1), 24-29.

Nasution, M. A., Silaban, R., \& Muchtar, Z. (2013). Penerapan Model Pembelajaran yang Mampu untuk Meningkatkan Hasil Belajar Kimia dan Karakter Komunikatif serta Percaya Diri pada Materi Kimia Larutan. Jurnal Ilmu Pendidikan Indonesia, 1(3), 39-52.

Pedaste, M., Mäeots, M., Siiman, L. A., De Jong, T., Van Riesen, S. A., Kamp, E. T., ... \& Tsourlidaki, E. (2015). Phases of inquiry-based learning: Definitions and the inquiry cycle. Educational research review, 14, 47-61.

Putri, Y. M. D., \& Meinita, Y. (2013). Pengaruh Metode Pembelajaran Inkuiri Terbimbing (Guided Inquiry) untuk Meningkatkan Hasil Belajar dan Kemampuan Berpikir Tingkat Tinggi (High Order Thinking Skill) Siswa Kelas X SMA Negeri 1 Malang pada Pokok Bahasan Hidrokarbon. Skripsi, Fakultas Keguruan dan Ilmu Pendidikan: Universitas Negeri Malang.

Thobroni, M.,\& Mustofa, A., (2013). Belajar dan pembelajaran (Pengembangan wacana dan Praktik Pembelajaran dalam Pembangunan Nasional). Yogjakarta: Ar-Ruzz Media.

Trianto, S. P., \& Pd, M. (2007). Model-model pembelajaran inovatif berorientasi Konstruktivistik. Jakarta: Prestasi Pustaka.

Tyas, A. S., \& Lazulva, L. (2018). Pengaruh Inkuiri Terbimbing melalui Media Adobe Flash terhadap Hasil Belajar Kimia. Jurnal Tadris Kimiya, 3(2), 182189.

Yolanda, Y., Pujiati, P., \& Nurdin, N. (2015). Efektivitas Model Pembelajaran PBL dan TPS dalam Meningkatkan Keterampilan Berpikir Kritis Siswa. JEE (Jurnal Edukasi Ekobis), 3(6).

\footnotetext{
This is an open access article under CC-BY-SA license (https://creativecommons.org/licenses/by-sa/4.0/)
} 